\title{
Broiler-Housing Conditions Affect the Performance
}

\section{-Author(s)}

\section{Mesa $D^{\prime}$ \\ Muniz E" \\ Souza A'I \\ Geffroy B ${ }^{\text {IV }}$}

Department of biochemistry and molecular biology, Federal University of Paraná, Brazil; dmesaf@unal.edu.co.

" Technical poultry manager, Poultry Division, Zoetis Brazil.

III Agricultural manager, JBS Foods Brazil.

IV INRA, UR1037 LPGP, Fish Physiology and Genomics, Campus de Beaulieu, 35000 Rennes, France.

\section{-Mail Address}

Corresponding author e-mail address Dany Mesa

Federal University of Paraná, Centro Politécnico, Jardim das Américas, 81.531-980,

Curitiba-Paraná- Brazil

Tel: (5541) 3366-0421

Email: dmesaf@unal.edu.co

\section{-Keywords}

Chickens, sheds, feed conversion ratio, mortality, welfare.

\section{ABSTRACT}

In the last decades animal production has considerably increased worldwide to sustain an ever-growing human population. Among animal reared for consumption purposes, chickens are undoubtedly one of the most successful, mainly due to their rapid growth rate. The development of broiler farming has been accompanied in recent years by a substantial attention to animal welfare. This study is aimed at assessing the effects of different housing conditions on both feed conversion ratio and mortality of male broiler flocks through a largescale study (more than 100 million birds) involving 977 farms belonging to one major producer. For this, we evaluated nine features of the housing system using a linear model with random effect. The features were: roofing, floor, drinkers, feeders, water source, color curtain color, management, light and ventilation. A total of 3516 poultry flocks were assessed. Positive ventilation, metal and clay roof, dirt floor and owner management were shown to reduced mortality. Concrete floor, negative ventilation, blue curtains, fluorescent lightening, owner management, tap water and well water significantly improved FCR. We discuss our findings in relation with economic constraints and provide advices to encourage farmers using simple devices that will improve both production and chicken survival.

\section{INTRODUCTION}

Breeding for faster growth rate has been associated with welfare problems encountered in commercial broilers. Pressured by consumers (Broom \& Reefmann, 2005), growing attention has been paid worldwide to increase broiler welfare (Gocsik et al., 2016). In 2007 the major world private certification agency: GLOBAL Good Agricultural Practice (GAP) was created (GLOBALGAP, 2016). GLOBAL-GAP is a pre-farm gate standard for good agricultural practices and covers different aspects of food safety, environmental protection and animal welfare (Holzapfel \& Wollni, 2014). Besides that, it provides standards for countries in the world. This includes Brazil, the first exporter of chicken meat worldwide (UBA, 2014). Most recommendations have been done in relation to stocking density, with the goal to avoid overcrowding, since over a density of $30 \mathrm{~kg} / \mathrm{m}^{2}$, growth rate is significantly reduced (Feddes et al., 2002). Many studies focused on broiler density, assessing welfare and growing were done (Cravener et al., 1992; Muniz et al., 2006; Ravindran et al., 2006). However, a study involving commercial broilers showed that housing conditions are more important than stocking density per se regarding welfare (Dawkins et al., 2004). Some other studies confirm the importance of environmental conditions (Bueno \& Rossi, 2006; Zi-guang et al., 2014).

Housing and management of broiler are designed to ensure optimum performance. Several aspects of broiler production have 
been overlooked such as food quality/quantity (Weeks et al., 2000; Apajalahti et al., 2004) and breeder (Griffin \& Goddard, 1994), in the same way as little is known about the role of different features of sheds in improving production. Some studies have focused in these gaps (Abreu et al., 2011), such as, performance in concrete floor or cage (Swain et al., 2002; Santos et al., 2012). No consensus has been obtained regarding the floor that should be used to maximize growth while maintaining welfare and meat quality. For instance, heater position and number of drinkers in the house have explained $56 \%$ of the variations in litter moisture and both season and ventilation explained $73 \%$ of the variation in air (Weaver \& Meijerhof, 1991; Nahm, 2003; Lovanh et al., 2007; Miles et al., 2011). Several other factors such as, feeder type, drinker type, type of lighting and even curtain colours, might also have an impact on environment quality affecting both performance and welfare (Dozier et al., 2005; Cordeiro et al., 2010; Hameed et al., 2012).

The present study was designed with the objective of determining the impact of features of different housing system on the feed conversion ratio (FCR) and indirect measure of bird welfare: Mortality.

\section{MATERIALS AND METHODS}

The data were kindly given by JBS Foods Brazil (one of the biggest companies producing broilers in Brazil), so that the owner gave full permission to use it. This did not involve endangered species.

As it is a statistical analysis of the biggest dataset of broiler production in the world, we do not have other information regarding sacrifice procedure other than those provided by certification. Indeed, a large number of chicken producing units of the JBS Foods are certified by international bodies such as: Global GAP, BRC, Alo Free and follow important codes of good practices of production and slaughter of global customers (GLOBALGAP, 2013).

Data collection: All data was collected over one year (2012) from 3516 commercial chicken flocks located in north region to state of Santa CatarinaBrazil, raised on 977 different farms belonging to one major producer company. The daily slaughtering of the production unit is about 160,000 chickens, essentially meant for export.

Flock is defined as a group of chickens placed in a house and present in the house at the same time. Typical commercial flock size was between 10,000 and 30,000 birds (Figure 1), with a mean of 29,340 individuals. The performance results of different broiler flocks were collected as well as the features of the shed from which they belonged. This represents data for 103,160,987 male broiler chickens.

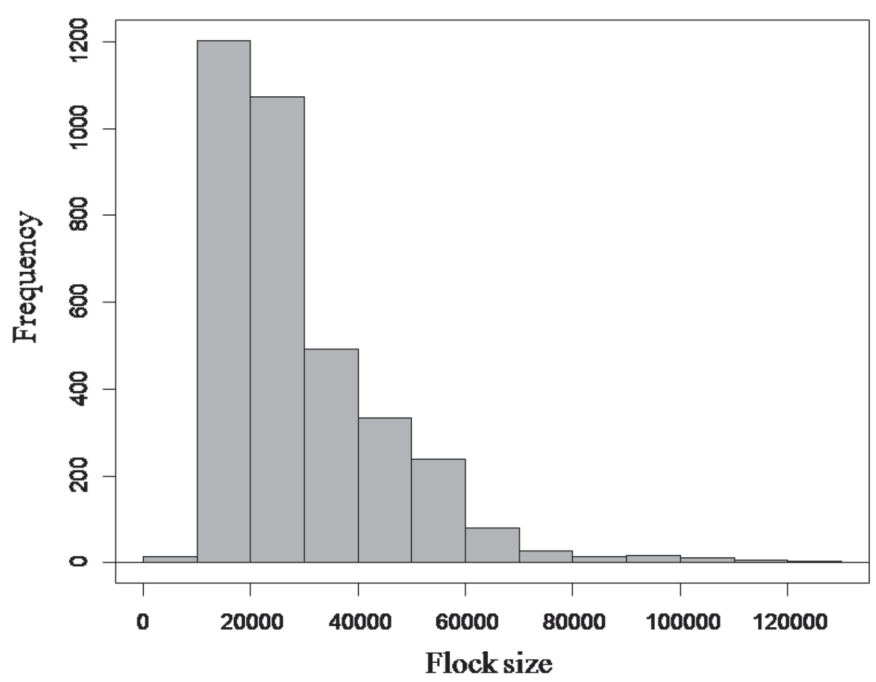

Figure 1 - Distribution of the number of individuals per flocks.

Birds and feed: Male broiler chicks Ross $308^{\circledR}$ breed were reared from one day old to forty-two day old. The chickens were fed ad libitum with a diet specific for each phase of growth, following the recommendations of the broiler management manual, which also lists the dry bulb temperatures required to achieve good growing performances. The air temperature inside the sheds for the first day was around $30^{\circ} \mathrm{C}$, slightly decreasing in the course of chicken development to attain a temperature of approximately $20^{\circ} \mathrm{C}$ at 42 days of age, following commercial recommendations. None of the farms controlled humidity directly, humidity varied between $60-70 \%$. All individuals were fed the same feed, provided by veterinary specialists from the major producer.

Features of sheds: A typical rearing house (also called a shed or barn) showed the following features: The size predominant was 40 by 400 feet $(12 \mathrm{~m}$ $\times 120 \mathrm{~m}$ ), insulated ceiling, and exterior curtain side walls. The mean density of chickens was 12 birds per $\mathrm{m}^{2}$, to ensure not to exceed the threshold of $33 \mathrm{~kg} / \mathrm{m}^{2}$. Daylight duration was between 13 hours in December and January and 10 hours in July.

We recorded the following information for each shed:

- Feeder type: Chain feeder or individual pans;

- Drinker type: Nipples or bell;

- Type of management of the broilers (owner or keeper). Owner: persons owning the holding 
where chickens are kept; Keeper: legal person responsible for or in charge of chickens

- Type of ventilation system (negative or positive): For negative, the air is forced from inside to outside, while fans work the opposite way for positive system.

- Floor type: concrete or dirt (beaten earth). All producers with concrete floor had the Global Gap certificate. Litter (wood shavings) to cover the floor. The litter was reused and disinfected for seven consecutive flocks with the same protocol in all farms for this study (Muniz et al., 2014).

- Origin of the water: spring water, tap water or well

- Type of lighting: incandescent or fluorescent (the same lighting program)

- Color of the curtains: blue or yellow

- Roofing material: clay, metal or concrete.

These data were then confronted with data of performance (Food conversion rate) and welfare (assessed through percentage of mortality of each flock).

Performance: Aiming at standardizing data to allow more accurate analysis, feed conversion ratio was adjusted to $2.0 \mathrm{~kg}$ live weight. Live weight was adjusted by dividing total flock weight by days until slaughter. Feed conversion ratio (FCR) was calculated dividing total flock feed intake by total flock weight gain during the grow-out. Corrected feed conversion ratio (CFCR), using CFCR for 2.0 standard live weight, was calculated using the following equation (Patricio et al., 2012):

$$
\mathrm{CFCR}=(\mathrm{SW}-\mathrm{AW}) / 3.2+\mathrm{FCR} \text {. }
$$

Where: $\mathrm{SW}=$ standard weight, $\mathrm{AW}=$ average flock weight, 3.2 = correction factor, $F C R=$ flock feed conversion ratio. Mortality was assessed at the end of the growing process.

Data analysis: The cFCR was correlated to mortality using a linear model with mixed effects (LMM) to take into account farm effects, which was added as random effect for the intercept. LMM are designed to handle grouping in the data and some farm delivered many data, such as an autocorrelation of the data likely occurred. To assess the impact of environmental variables on mortality, we first used a linear model. Model-fitting began with a saturated model including all variables ( 9 variables). Then we applied the step AIC function that allows performing stepwise model selection based on the AIC, and as such allows selecting the more parsimonious model.
Once this selection process was applied, the more parsimonious model was run using LMM. The same procedure of model selection was applied to assess the impact of environmental variables on CFCR.

All statistical analyses were performed using $R$ software ( $R$ Development Core Team 2009), in particular the "MASS" package (Venables \& Ripley, 2002) for the step AIC function, the "Ime4" package (Bates \& Maechler, 2009) for linear model with mixed effects and the "effects" package for the design of graphs.

\section{RESULTS}

Mortality averaged was 4\% and CFCR averaged 1.4. Neither mortality nor CFCR were correlated to the size of the flock (mixed linear model, p-value: 0.37 and 0.07 respectively). CFCR was positively and significantly correlated to mortality (linear model with mixed effects, $P$-value: 0.007, Figure 2), although the adjusted R-squared of the linear model was really low (adjusted R-squared $=0.001$ ).

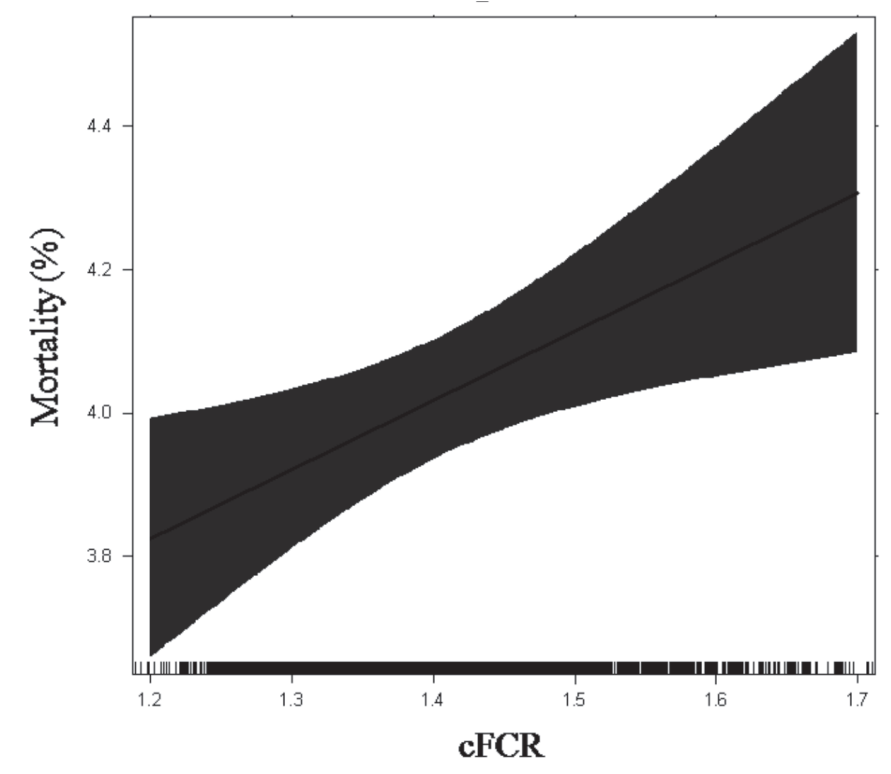

Figure 2 - Correlation between corrected feed conversion ratio (CFCR) and mortality. The black line represents the linear model with mixed effects (LMM) and the shaded area is the 95-percent confidence envelope around the fitted effects.

In the most parsimonious model, explaining mortality variance, the following variables were selected: Color of the curtains, feeders, ventilation type, roofing material, management and floor type. Among these variables, ventilation type, roofing material, management and floor type significantly impacted the mortality in our linear model with random effects (Table 1). Positive ventilation, metal and clay roof, dirt floor and owner management led to lower mortality (Table 1, Figure 3). 
Table 1 - Effects of different variables on mortality

\begin{tabular}{|c|c|c|c|c|}
\hline \multicolumn{5}{|c|}{ Linear mixed model fit by REML } \\
\hline \multicolumn{5}{|l|}{ Random effects: } \\
\hline Groups Names & Variance & Std.Dev. & & \\
\hline Farm (Intercept) & 0.5943 & 0.7709 & & \\
\hline Residual & 2.8364 & 1.6842 & & \\
\hline \multicolumn{5}{|l|}{ Number of observations: 3516} \\
\hline \multicolumn{5}{|l|}{ Group Farm 977} \\
\hline \multicolumn{5}{|l|}{ Fixed effects: } \\
\hline & Estimate & Std. Error & t value & $p$-value \\
\hline (Intercept) & 4.96 & 0.13 & 38.68 & $<0.001 * * *$ \\
\hline Color.curtainsYellow & 0.10 & 0.09 & 1.13 & $>0.05$ \\
\hline FeedersManual & 0.18 & 0.11 & 1.61 & $>0.05$ \\
\hline Ventilation.typePositive & -0.25 & 0.11 & -2.37 & $<0.001 * * *$ \\
\hline Roofing materialsConcrete & 0.20 & 0.08 & 2.46 & $<0.001 * * *$ \\
\hline Roofing.materials Metal & -0.62 & 0.38 & -1.64 & $>0.05$ \\
\hline Management.Owner & -0.35 & 0.09 & -3.83 & $<0.001 * * *$ \\
\hline FloorDirt & -0.92 & 0.10 & -8.95 & $<0.001 * * *$ \\
\hline
\end{tabular}

Table 1 : Outputs of the linear mixed model (LMM) testing the effects of the colour of the curtains, type of feeders, type of ventilation, roofing material, management type and floor type on mortality. The farm was used as a random effect. REML: Residual Maximum Likelihood estimation criterion ${ }^{* * *}$ Significant value $<0.001$.
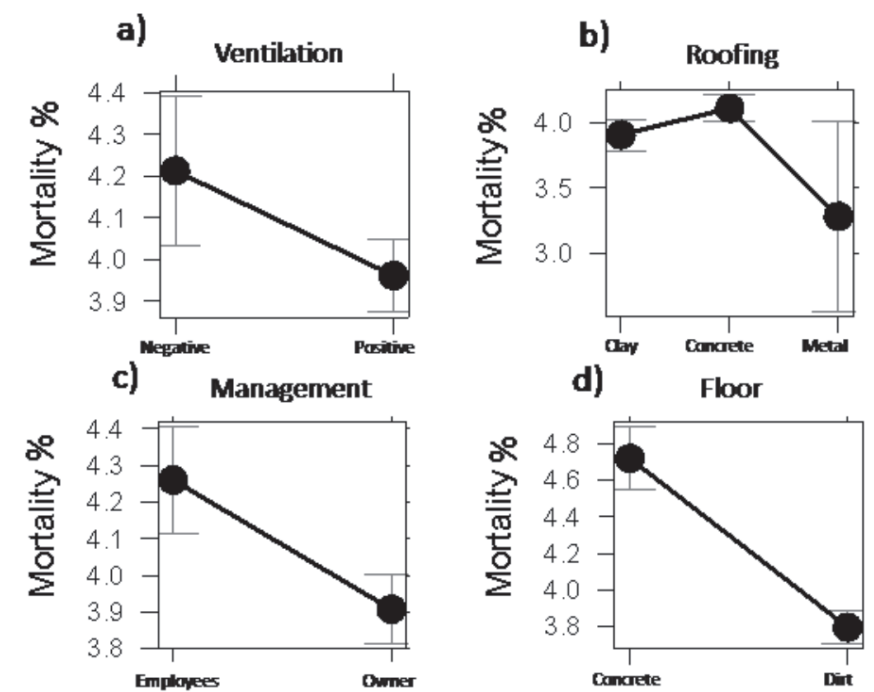

Figure 3 - Fitted values for the variables a) ventilation type, b) roofing material, c) management type and d) floor type, that significantly impacted mortality. Graphs represent only significant terms from the linear model with random effects (see Table 1). Black bar: $95 \%$ interval for the fitted value.

In the most parsimonious model, explaining CFCR variance, the following variables were selected: roofing material, ventilation type, floor type, feeders, color of the curtains, type of lighting, management and origin of the water. Among these variables, the ventilation type, the floor type, the color of the curtains, the type of lighting, the management and the origin of the water significantly impacted the male CFCR in our linear model with random effects (Table 2). All, concrete floor, negative ventilation, blue curtains, fluorescent lightening, owner management, tap water and water coming from the well significantly improved the male cFCR efficiency (Table 2, Figure 4).

Table 2 - Effects of different variables on corrected feed conversion ratio (CFCR)

\begin{tabular}{|c|c|c|c|c|}
\hline \multicolumn{5}{|c|}{ Linear mixed model fit by REML } \\
\hline \multicolumn{5}{|l|}{ Random effects } \\
\hline Groups Name & Variance & Std.Dev. & & \\
\hline Farm (Intercept) & 0.0013 & 0.037 & & \\
\hline Residual & 0.0061 & 0.078 & & \\
\hline \multicolumn{5}{|c|}{ Number of observations: 3516} \\
\hline \multicolumn{5}{|l|}{ Groups Farm: 977} \\
\hline \multicolumn{5}{|l|}{ Fixed effects: } \\
\hline & Estimate & Std. Error & t value & $p$-value \\
\hline (Intercept) & 1.4 & 0.007 & 198.4 & $<0.001 * * *$ \\
\hline Roofing: Concrete & 0.0036 & 0.004 & 0.91 & $>0.05$ \\
\hline Roofing: Metal & -0.019 & 0.018 & -1.05 & $>0.05$ \\
\hline Ventilation: Positive & 0.01 & 0.005 & 2.07 & $<0.01 * *$ \\
\hline Floor: Dirt & 0.024 & 0.005 & 4.95 & $<0.001 * * *$ \\
\hline Feeders: Manual & -0.01 & 0.005 & -1.89 & $>0.05$ \\
\hline Curtains: Yellow & 0.03 & 0.004 & 6.96 & $<0.001 * * *$ \\
\hline Lighting: Incandescent & 0.015 & 0.004 & 4.19 & $<0.001 * * *$ \\
\hline Management: Owner & -0.045 & 0.004 & -10.3 & $<0.001 * * *$ \\
\hline Water origin: Tap water & -0.04 & 0.009 & -3.98 & $<0.001 * * *$ \\
\hline Water origin: Well & -0.02 & 0.004 & -4.24 & $<0.001^{* * *}$ \\
\hline
\end{tabular}

Table 2: Outputs of the linear mixed model (LMM) testing the effects of roofing materials, ventilation type, floor type, feeder type, colour of the curtains, lighting, management and water origin on corrected feed conversion ratio (CFCR). The farm was used as a random effect. REML: Residual Maximum Likelihood estimation criterion *** Significant value $<0.001$ and ${ }^{* *}$ Significant value $<0.01$.
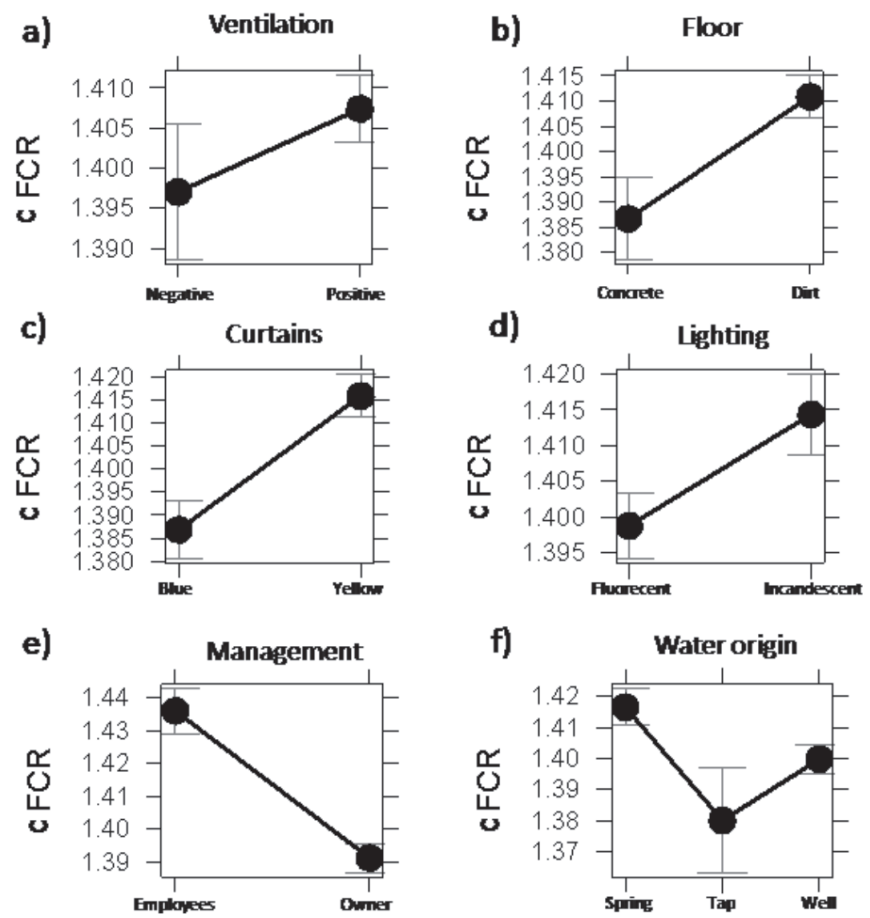

Figure 4 - Fitted values for the variables a) ventilation type, b) floor type, c) curtains color, d) type of lighting, e) management type and f) water origin, that significantly impacted corrected feed conversion ratio (CFCR). Graphs represent only significant terms from the linear model with random effects (see Table 2). Black bar: $95 \%$ interval for the fitted value. 


\section{DISCUSSION}

Mortality was independent of flock size but was, however, positively correlated to CFCR such that high production efficiency (low CFCR) was also linked to low mortality. This result should however be taken with caution since it might highly depend to the very high number of flock tested (3516), owing to the low percentage of explanation (adjusted $r$-squared $=0.001$ ). The positive relationship between mortality and cFCR was probably attained through the decline of stress. Indeed, mortality and impaired growth rate are highly correlated to corticosteroid levels (Dawkins et al., 2004; Jones et al., 2005) ammonia and diseases (Reece et al., 1980; Kristensen \& Wathes, 2000; Chapman et al., 2002; Santana et al., 2012), these conditions equally might affect both FCR and mortality. We suppose it is not only stress that might cause this positive relationship, the feed and water quality play an important role (King, 1996; Amerah et al., 2007) among many other factors. Moreover all flocks used in this study were apparently healthy birds. A specific combination of housing features and management procedures have contributed to the amelioration of broiler conditions leading to high production efficiently and increased welfare (Meluzzi \& Sirri, 2009; Jacobs et al., 2016).

Management: Broilers kept by owners reached higher performances (CFCR) and lower mortality when compared to broilers reared by employees. Nevertheless, neither CFCR nor mortality was significantly affected by flock size and bigger flocks tended to have better cFCR ( $P$-value: .07). As a general rule, performance of human managers might vary greatly in livestock production, with some producing consistently better results than others. Concerning present data, it is likely that owners were more dedicated than employees in keeping the flock either through their experience of managing broiler production (compared to new employees) or by being directly linked to their financial investment. To the best of our knowledge, this is the first report to highlight the relevance of the producers within the system.

Water origin: In several regions of the world, water availability is the most limiting factor for producing broilers. In other regions, it is rather the water quality that will directly affect production (Barton, 1996). In the present study both tap water and water coming from wells improved feed conversion ratio. In general, it is more difficult to maintain a consistent water quality when using spring water compared to tap water or water coming from wells, although poor storage might also negatively influence quality (Penz, 2003).
Water has several physico-chemical (Barton, 1996) and microbiological (Lee \& Cole, 1994; Grizzle et al., 1997) characteristics affecting broilers' performances. The better CFCR observed with tap water could be the result of a rigorous water management undertaken by the public system. The constant flow chlorination might have improved the microbiological quality of the water by diminishing the relative number of faecal coliforms (Valias \& Silva, 2001), therefore enhancing broiler performance. While nipple drinkers were associated with possible injuries (Jones et al., 2005) the present study failed at finding an effect of drinker type on both CFCR and mortality.

Curtains: Although the curtain colors could, at first, appear anecdotic, some studies highlighted its importance on birds' growth and welfare (Olanrewaju et al., 2006; Abreu et al., 2011). Blue curtains were selected in the more parsimonious model, explaining lower mortality (although not significant) and birds raised in houses with blue curtains achieved a significantly better CFCR than those raised in houses equipped with yellow curtains. Present results are in contradiction with those obtained by (Abreu et al., 2011), who found that broilers reared in houses with yellow curtains presented on average the best FCR (although this depended on flock, season and lighting program). The main difference between studies relies on the number of birds; while Abreu et al. (2011) conducted their study on experimental conditions (200 birds per flock, $n=6$ ), we used a more realistic approach by providing data on commercial houses. Present results are in line with the assumption that blue curtains would lead to high performance through the lowering of physical activity and energy expenditure in darker conditions (Lewis \& Morris, 2000). However, Abreu et al. (2011) showed that curtain colour (yellow or blue) did not influence light intensity inside the houses, and positive effects of blue curtain might rather be mediated by light properties. In broilers, both blue and green lights were shown to promote growth (Rozenboim et al., 1999a; Rozenboim et al., 1999b; Rozenboim et al., 2004), probably linked to effective stimulation of testosterone secretion (Cao et al., 2008). In addition, blue light wave length was shown to stimulate immunity and alleviate stress response (Xie et al., 2008). In addition, exposure of the broilers to blue light just before slaughtering showed potential to be used in modern slaughter houses to offer a comfortable atmosphere (Barbosa et al., 2013). In other taxon, such as fish, blue light was also shown to reduce stress compared to both white and green light (Volpato \& Barreto, 2001; Pereira Silva et al., 2012). 
Lightening: Artificial lights differ consistently from natural light in terms of intensity, color and flicker intensity. Light is highly important for several life history traits such as reproduction and growth (Huth \& Archer, 2015b; Olanrewaju et al., 2016b). In the present study, light source did not affected mortality, while it impacted CFCR, with fluorescent lightening providing better results compared to incandescent lights. A decade ago, incandescent bulbs were the standard "reviewed in Olanrewaju et al. (2006)", but fluorescent lamps are increasingly used, mainly due to their longer lifetime (approximately 20,000 hours)(Darre \& Rock, 1995). When the choice between two types of light was given to chickens, the birds clearly chose fluorescent lamps over incandescent lamps (Widowski et al., 1992; Kristensen et al., 2004). Kristensen et al. (2006), compared two different fluorescent light sources and did not detect any effects on feed intake, weight gain and mortality. To our knowledge, this is the first report assessing the difference in FCR between fluorescent lamps and incandescent bulbs. The fact that fluorescent lamps improve poultry performance is of great interest, since it will also allow long-term economic benefits (Andrews \& Zimmermann, 1990)due to their higher performance when compared to incandescent bulbs with much shorter lifetime (i.e. about 750-2000 hours) (Darre \& Rock, 1995). Moreover, the poultry industry is currently undergoing a shift to alternative lighting sources such as light-emitting diode (LED) bulbs, that have associated increased energy savings, they may affect the bird's growth and well-being (Huth \& Archer, 2015a; Olanrewaju et al., 2016a). In addition, chickens exposed to LED bulbs presented better performance than chickens under the fluorescent lamps(Mendes et al., 2013b).

Roofing: This result was surprising, it does not affect the performance of the birds in our statistical model, but the concrete roof appears to influence mortality of chickens. Explaining this could appears tricky, since there are no specific studies assessing the effect of various materials for roofs in broiler sheds. To this result we dare suggest the hypothesis that clay tile can act in a more thermal manner in comparison to concrete tile, in other words, the clay could act as an insulating medium between the external environmental conditions and the inside of the shed, on the contrary the cement could pass more easily the external conditions to the interior, though this is just a hypothesis in which could run an experiment.

The role of ventilation type: Ventilation plays a key role in poultry production since it allows counter balancing negative effects of stocking density by improving air quality (Puron et al., 1995; Mendes et al., 2013a), allowing heat dissipation and removing excessive moisture. Keeping the litter dry and providing sufficiently oxygen to meet the birds' metabolic demand are highly important to improve animal welfare (Cordeiro et al., 2010; Amaral et al., 2011). For negative pressure, the air is forced from inside to outside, while fans works the opposite way for positive pressure. Negative pressure generally results in effective mixing of air and higher air uniformity within the shed compared to positive pressure. This feature has a considerable impact on both CFCR and mortality. Negative pressure was associated with high growing performances, even at high densities (Feddes et al., 2002). Interestingly, negative pressure appeared to significantly improve CFCR in the present study, while its effects were deleterious considering overall bird welfare. Respiratory disease generally results from a combination of negative variables such as microorganisms and type of gases encountered in the shed, mainly ammonia. Heier et al. (2002), showed that broiler mortality was lesser when fans were used in comparison with low-pressure systems.

A poor ventilation system is probably related to bad litter quality which is in turn related to foot pad dermatitis (Martrenchar et al., 2002), disease that prejudice the welfare and performance of the birds(Kaukonen et al., 2016).

Concrete Floor: Concrete floor significantly improved cFCR, compared to hard-packed dirt floors. This finding does not support results from Abreu et al. (2011) who reported no difference in broilers' performance according to the type of floors. When comparing floor and cage, broilers reared on concrete floor consumed significantly more feed than in cage (Swain \& Sundaram, 2000; Rodríguez et al., 2005). However, regarding bird welfare, dirt floor significantly diminished mortality when compared to concrete floor. Again, our results are in disagreement with Abreu et al. (2011) findings, who stressed that both total mortality and sudden death were higher when broilers were raised on hard-packed dirt floors. Differences between studies are mainly explained by differences in the number of birds used and by experimental procedure, as underlined above. There is empirical evidence that concrete floor produce wetter litters than dust floor (Kunkle et al., 1981). Litter quality is of high importance since broiler chickens generally spend their entire life in contact with it (Smith, 1956). The fact of being raised on wet litter might inhibit dust-bathing. This behavior is essential since it allows diminishing stress; particularly in young chicks as scratching behavior disappear with 
ontogeny (Bessei, 2006). However, concrete floors are recommended by the GLOBAL-GAP since it promotes poultry house disinfection (GLOBALGAP, 2016).

Economic consequences and recommendations: To date, Brazil is the third largest producer of broiler in the world (after The United States and China) employing directly or indirectly 3.6 million people (producers, processing companies and exporters) principally in the Southern and South-eastern states (UBA, 2014). As such, identifying factors that will allow improving both survival and performance would not only benefit Brazilian farmers, but also farmers from other developing countries.

Like in many South-American countries, Brazilian legislation is outdated and does not specifically address animal welfare issues (Silva et al., 2011). Most producers rely on information given by the GLOBAL-GAP that is starting to take into account welfare preoccupation, though most recent analyses on the subject highlighted that more rigorous standards should urgently be developed (Silva et al., 2011). Welfare is currently also being recognized by consumers as an essential point to purchase products (Vanhonacker \& Verbeke, 2009; Gerini et al., 2016). For instance, in a survey conducted in 2011 in Brazil, 76 \% of the consumers worried about welfare and $63 \%$ of consumers expressed willingness to pay more if this implied an improvement for the chicken welfare (Silva et al., 2011).

Density of broilers account noticeably for their welfare, with higher density often associated with heat-related issues (Shanawany, 1988; Buijs et al., 2009; Abudabos et al., 2013). Nevertheless some studies reported that a certain threshold of bird density is necessary to increase feeding through socially facilitated behaviors (Collins \& Sumpter, 2007). Assuming no reduction in the performance of broilers, total production cost $(\$ / \mathrm{kg})$ should decrease drastically with increasing density (Feddes et al., 2002). Hence, a good compromise should be attained in order to not impair both FCR and survival, while conserving low economic inputs in a competitive market place. Long-term good results should be achieved by using a combination of factors related to housing conditions (Manning et al., 2007). In Brazil, most farmers use hard-packed dirt floors, mainly linked to their lower building cost relative to concrete floor (Fioretin, 2006). On the one hand, concrete floor improve consistently CFCR. On the other hand, dirt floors provide much better results regarding survival, than concrete floors. CFCR increased using concrete floor compared to dirt floor, while mortality decreased using dirt floor relative to concrete floor (total mortality $3.8 \%$ compared to $4.7 \%$, roughly 300 broilers for a representative farm). Considering that survival rate is the most useful indirect measure for animal wellbeing, we would thus recommend using dirt floor for broiler welfare. Conversely, while positive pressure might slightly improve survival, it might greatly impair CFCR, and we would thus recommend the use of negative pressure, with fan forcing the air from inside to outside. Regarding our results, other recommended features are blue curtains, fluorescent lightning and either tap water or water coming from wells.

Considering both the span of the evaluation (comparing about 1000 farms) and the number of chicken used (more than 100million), the present study provide rich material and assess, with a strong statistical support, the importance of various basic an necessary housing conditions in improving both cFCR and mortality in broiler production, we believe it is imperative to explore all alternative approaches allowing maximizing the production, while improving welfare standards. We emphasize the importance of the management of birds given by the owners compared to employees, as well as the positive impact of the type of water, color of the curtains and ventilation system on the welfare and performance of the broilers.

\section{ACKNOWLEDGMENTS}

We would like to thank Diva Visbiski for encouraging the discussion. We also thank Peter Ward Blakeney by the English revision in the manuscript as well as JBS Foods Brazil for providing data. We have no conflict of interest.

\section{REFERENCES}

Abreu V, Abreu P, Jaenisch F, Coldebella A, Paiva D. Effect of floor type (dirt or concrete) on litter quality, house environmental conditions, and performance of broilers. Brazilian Journal of Poultry Science 2011;13(2):127-137.

Abudabos A, Samara E, Hussein E, Al-Atiyat RM, Al-Haidary A. Influence of stocking density on welfare indices of broilers. Italian Journal of Animal Science 2013;12(2):213-218

Amaral AG, Yanagi T, Lima RR, Teixeira VH, Schiassi L. Efeito do ambiente de produção sobre frangos de corte sexados criados em galpão comercial. Arquivo Brasileiro de Medicina Veterinaria e Zootecnia 2011;63(3):649658 .

Amerah AM, Ravindran $V$, Lentle RG, Thomas DG. Feed particle size: Implications on the digestion and performance of poultry. World's Poultry Science Journal 2007;63(3):439-455.

Andrews DK, Zimmermann NG. A comparison of energy efficient broiler house lighting sources and photoperiods. Poultry Science 1990;69(9):1471-1479. 
Apajalahti J, Kettunen A, Graham H. Characteristics of the gastrointestinal microbial communities, with special reference to the chicken. World's Poultry Science Journal 2004;60(2):223-232

Barbosa CF, Carvalho RH, Rossa A, Soares AL, Coró FAG, Shimokomaki $\mathrm{M}$, Ida El. Commercial preslaughter blue light ambience for controlling broiler stress and meat qualities. Brazilian Archives of Biology and Technology 2013;56(5):817-821.

Barton TL. Relevance of water quality to broiler and turkey performance. Poultry Science 1996;75(7):854-856

Bates D, Maechler M. Ime4: linear mixed-effects models using S4 classes. R package; 2009 .

Bessei W. Welfare of broilers: a review. World's Poultry Science Journal 2006;62(3):455-466.

Broom DM, Reefmann N. Chicken welfare as indicated by lesions on carcases in supermarkets. British Poultry Science 2005;46(4):407-414.

Bueno L, Rossi LA. Comparação entre tecnologias de climatização para criação de frangos quanto a energia, ambiência e produtividade. Revista Brasileira de Engenharia Agrícola e Ambiental 2006;10(2):497504.

Buijs S, Keeling L, Rettenbacher S, Van Poucke E, Tuyttens FAM. Stocking density effects on broiler welfare: Identifying sensitive ranges for different indicators. Poultry Science 2009;88(8):1536-1543.

Cao J, Liu W, Wang Z, Xie D, Jia L, Chen Y. Green and blue monochromatic lights promotg Growth and development of broilers via stimulating testosterone secretion and myofiber growth. The Journal of Applied Poultry Research 2008;17(2):211-218.

Chapman HD, Cherry TE, Danforth HD, Richards G, Shirley MW, Williams RB. Sustainable coccidiosis control in poultry production: the role of live vaccines. International Journal of Parasitology 2002;32(5):617-629.

Collins LM, Sumpter DJT. The feeding dynamics of broiler chickens. Journal of The Royal Society Interface 2007;4(12):65-72.

Cordeiro MB, Tinôco IFF, Silva JN, Vigoderis RB, Pinto FAC, Cecon PR. Conforto térmico e desempenho de pintos de corte submetidos a diferentes sistemas de aquecimento no período de inverno. Revista Brasileira de Zootecnia 2010;39(1):217-224

Cravener TL, Roush WB, Mashaly MM. Broiler production under varying population densities. Poultry Science 1992;71(3):427-433.

Darre MJ, Rock JS. Compact fluorescent lamps under commercial poultry house conditions. The Journal of Applied Poultry Research 1995;4(1):105-108.

Dawkins M, Donnelly CA, Jones TA. Chicken welfare is influenced more by housing conditions than by stocking density. Nature 2004;427(6972):342-344.

Dozier WA, Lott BD, Branton SL. Live performance of male broilers subjected to constant or increasing air velocities at moderate temperatures with a high dew point. Poultry Science 2005;84(8):1328-1331

Feddes J, Emmanuel E, Zuidhoft M. Broiler performance, body weight variance, feed and water intake, and carcass quality at different stocking densities. Poultry Science 2002;81(6):774-779.

Fioretin L. Processos de tratamento para a reutilização de cama de aviário: Aspectos bacteriológicos. In: Conferência APINCO de Ciência e Tecnologia Avícolas; 2006; Santos, São Paulo. Brasil; 2006. p.17-24.

Gerini F, Alfnes F, Schjøll A. Organic- and Animal Welfare-labelled Eggs: Competing for the Same Consumers? Journal of Agricultural Economics 2016;67(2):471-490.
GLOBALGAP. Animal welfare add-on module for poultry / broiler chicken Control points and compliance criteria [cited 2013]. Available from: http://www.globalgap.org/export/sites/default/.content/.galleries/ documents/130215_gg_add-on_aw_py_cpcc_v1_0_en.pdf.

GLOBALGAP. Poultry standard [cited 2016]. Available from: http://www. globalgap.org/uk_en/for-producers/livestock/PY/.

Gocsik É, Brooshooft SD, de Jong IC, Saatkamp HW. Cost-efficiency of animal welfare in broiler production systems: A pilot study using the Welfare Quality ${ }^{\circledR}$ assessment protocol. Agricultural Systems 2016;146:55-69.

Griffin HD, Goddard C. Rapidly growing broiler (meat-type) chickens. Their origin and use for comparative studies of the regulation of growth. International Journal of Biochemistry 1994;26(1):19-28.

Grizzle JM, Armbrust TA, Bryan MA, Saxton AM. Water quality II: The effect of water nitrate and bacteria on broiler growth performance. The Journal of Applied Poultry Research 1997;6(1):48-55

Hameed T, Bajwa M, Abbas F, Sahota A, Masood Tariq M, Hassan Khan S, Abbas Bokhari F. Effect of housing system on production performances of different broiler breeder strains. Pakistan Journal of Zoology 2012;44(6):1683-1687

Heier BT, Høgåsen HR, Jarp J. Factors associated with mortality in Norwegian broiler flocks. Preventive Veterinary Medicine 2002;53(1-2):147-158.

Holzapfel S, Wollni M. Is GlobalGAP Certification of Small-Scale Farmers Sustainable? Evidence from Thailand. The Journal of Development Studies 2014;50(5):731-747.

Huth JC, Archer GS. Comparison of Two LED Light Bulbs to a Dimmable CFL and their Effects on Broiler Chicken Growth, Stress, and Fear. Poultry Science 2015a;94(9):2027-2036

Huth JC, Archer GS. Effects of LED lighting during incubation on layer and broiler hatchability, chick quality, stress susceptibility and post-hatch growth. Poultry Science 2015b;94(12):3052-3058.

Jacobs L, Delezie E, Duchateau L, Goethals K, Ampe B, Lambrecht E, et al. Effect of post-hatch transportation duration and parental age on broiler chicken quality, welfare, and productivity. Poultry Science 2016;95(9):1973-1979

Jones TA, Donnelly CA, Stamp Dawkins M. Environmental and management factors affecting the welfare of chickens on commercial farms in the United Kingdom and Denmark stocked at five densities. Poultry Science 2005;84(8):1155-1165

Kaukonen E, Norring M, Valros A. Effect of litter quality on foot pad dermatitis, hock burns and breast blisters in broiler breeders during the production period. Avian Pathology 2016;1-15

King AJ. Water Quality and Poultry Production. Poultry Science $1996 ; 75(7): 852-853$

Kristensen HH, Aerts JM, Leroy T, Berckmans D, Wathes CM. Using light to control activity in broiler chickens. British Poultry Science 2004;45(sup1):S30-S31

Kristensen HH, Perry GC, Prescott NB, Ladewig J, Ersboll AK, Wathes CM. Leb health and performance of broiler chickens reared in different light environments. British Poultry Science 2006;47(3):257-263.

Kristensen $\mathrm{HH}$, Wathes CM. Ammonia and poultry welfare: a review. World's Poultry Science Journal 2000;56(3):235-245.

Kunkle WE, Carr LE, Carter TA, Bossard EH. Effect of flock and floor type on the levels of nutrients and heavy metals in broiler litter. Poultry Science 1981;60(6):1160-1164 
Lee RJ, Cole SR. Internal quality control samples for water bacteriology. Journal of Applied Bacteriology 1994;76(3):270-274.

Lewis PD, Morris TR. Poultry and coloured light. World's Poultry Science Journal 2000;56(3):189-207

Lovanh N, Cook KL, Rothrock MJ, Miles DM, Sistani K. Spatial shifts in microbial population structure within poultry litter associated with physicochemical properties. Poultry Science 2007;86(9):1840-1849.

Manning L, Chadd SA, Baines RN. Key health and welfare indicators for broiler production. World's Poultry Science Journal 2007;63(1):46-62.

Martrenchar A, Boilletot E, Huonnic D, Pol F. Risk factors for foot-pad dermatitis in chicken and turkey broilers in France. Preventive Veterinary Medicine 2002;52(3/4):213-226.

Meluzzi A, Sirri F. Welfare of broiler chickens. Italian Journal of Animal Science 2009;8 Suppl 1:161-173.

Mendes A, Moura D, Nääs I, Morello G, Carvalho T, Refatti R, Paixão S. Minimum ventilation systems and their effects on the initial stage of turkey production. Brazilian Journal of Poultry Science 2013a;15(1):713.

Mendes AS, Paixão SJ, Restelatto R, Morello GM, Jorge de Moura D, Possenti JC. Performance and preference of broiler chickens exposed to different lighting sources. The Journal of Applied Poultry Research 2013b;22(1):62-70.

Miles DM, Rowe DE, Cathcart TC. Litter ammonia generation: Moisture content and organic versus inorganic bedding materials. Poultry Science 2011;90(6):1162-1169.

Muniz E, Fascina V, Pires P, Carrijo A, Guimarães E. Histomorphology of bursa of Fabricius: Effects of stock densities on commercial broilers. Brazilian Journal of Poultry Science 2006;8(4):217-220.

Muniz E, Mesa D, Cuaspa R, Souza AM, Santin E. Presence of Salmonella spp. in reused broiler litter. Revista Colombiana de Ciencias Pecuarias 2014;27(1):12-27.

Nahm KH. Evaluation of the nitrogen content in poultry manure. World's Poultry Science Journal 2003;59(1):77-88.

Olanrewaju HA, Miller WW, Maslin WR, Collier SD, Purswell $J \mathrm{~L}$, Branton SL. Effects of light sources and intensity on broilers grown to heavy weights. Part 1: Growth performance, carcass characteristics, and welfare indices. Poultry Science 2016a;95(4):727-735.

Olanrewaju HA, Purswell JL, Collier SD, Branton SL. Influence of Light Sources and Photoperiods on Blood Physiological variables Broilers grown to heavy weights. FASEB Journal 2016b;30(1Suppl):946-949.

Olanrewaju HA, Thaxton JP, Dozier WA, Purswell J, Roush WB, Branton $\mathrm{SL}$. A review of lighting programs for broiler production. International Journal of Poultry Science 2006;5(4):301-308.

Patricio I, Mendes A, Ramos A, Pereira D. Overview on the performance of Brazilian broilers (1990 to 2009). Brazilian Journal of Poultry Science 2012;14(4):233-238

Penz AM. Importância da água na produção de frangos de corte. Anais do $4^{\circ}$ Simpósio Brasil Sul de Avicultura; 2003; Chapecó, Santa Catarina. Brasil; 2003. p 112-131.

Pereira Silva EM, Melo MP, Oliveira RHF, Pugine SMP. Atividade da catalase e da lactato desidrogenase em tilápias submetidas a estresse de confinamento: Efeito da cor do ambiente. Ciência Rural 2012;42(5):894-899.

Puron D, Santamaria R, Segura JC, Alamilla JL. Broiler performance at different stocking densities. The Journal of Applied Poultry Research 1995;4(1):55-60.
Ravindran V, Thomas DV, Thomas DG, Morel PCH. Performance and welfare of broilers as affected by stocking density and zinc bacitracin supplementation. Animal Science Journal 2006;77(1):110-116.

Reece FN, Lott BD, Deaton JW. Ammonia in the atmosphere during brooding affects performance of broiler chickens. Poultry Science 1980;59(3):486-488.

Rodríguez B, Valdivié M, Dieppa O. Daños corporales asociados a altas densidades de pollos en jaulas. Revista Cubana de Ciencia Agrícola 2005;39(1):61-66

Rozenboim I, Biran I, Chaiseha Y, Yahav S, Rosenstrauch A, Sklan D, et al. The effect of a green and blue monochromatic light combination on broiler growth and development. Poultry Science 2004;83(5):842-845.

Rozenboim I, Biran I, Uni Z, Robinzon B, Halevy O. The effect of monochromatic light on broiler growth and development. Poultry Science 1999a;78(1):135-138.

Rozenboim I, Robinzon B, Rosenstrauch A. Effect of light source and regimen on growing broilers. British Poultry Science 1999b;40(4):452457.

Santana ES, Andrade MA, Rocha TM, Stringhini JH, Café MB, Jayme VdS, et al. Performance of broilers experimentally inoculated with Salmonella Typhimurium and fed diets with addition of lactulosis. Revista Brasileira de Zootecnia 2012;41(8):1884-1889.

Santos FBO, Santos AA, Oviedo EO, Ferket PR. Influence of housing system on growth performance and intestinal health of Salmonella-challenged broiler chickens. Current Research in Poultry Science 2012;2(1):1-10.

Shanawany MM. Broiler performance under high stocking densities. British Poultry Science 1988;29(1):43-52.

Silva R, Nääs I, Broom D, O'Driscoll K. Poultry welfare scenario in South America: norms and regulations. Brazilian Journal of Poultry Science 2011:13(2):83-89.

Smith RC. Kind of litter and breast blisters on broilers. Poultry Science 1956;35(3):593-595

Swain BK, Sundaram RNS. Effect of different types of litter material for rearing broilers. British Poultry Science 2000;41(3):261-262.

Swain BK, Sundaram RNS, Barbudhe SB, Nirmale AV. Influence of cage and deep litter rearing systems on the performance of broilers. Indian Veterinary Journal 2002;79(5):467-470.

UBA. Relatório Anual União Brasileira de Avicultura [cited 2014]. Available from: http://www.brazilianchicken.com.br/home/publicacoes.

Valias A, Silva E. Estudo comparativo de sistemas de bebedouros na qualidade microbiológica da água consumida por frangos de corte. Brazilian Journal of Poultry Science 2001;3(1):83-89.

Vanhonacker F, Verbeke W. Buying higher welfare poultry products? Profiling Flemish consumers who do and do not. Poultry Science 2009;88(12):2702-2711.

Venables WN, Ripley BD. Modern applied statistics with S. 4th ed. New York: Springer; 2002

Volpato GL, Barreto RE. Environmental blue light prevents stress in the fish Nile tilapia. Brazilian Journal of Medical and Biological Research 2001:34(8):1041-1045.

Weaver W, Meijerhof R. The effect of different levels of relative humidity and air movement on litter conditions, ammonia levels, growth, and carcass quality for broiler chickens. Poultry Science 1991;70(4):746755. 
Weeks CA, Danbury TD, Davies HC, Hunt P, Kestin SC. The behaviour of broiler chickens and its modification by lameness. Applied Animal Behaviour Science 2000;67(1):111-125.

Widowski TM, Keeling LJ, Duncan IJH. The preferences of hens for compact fluorescent over incandescent lighting. Canadian Journal of Animal Science 1992;72(2):203-211.
Xie D, Wang ZX, Dong YL, Cao J, Wang JF, Chen JL, et al. Effects of monochromatic light on immune response of broilers. Poultry Science 2008; 87(8):1535-1539.

Zi-guang Z, Jian-hong L, Xiang L, Jun B. Effects of Housing systems on behaviour, performance and welfare of fast-growing broilers. AsianAustralasian Journal of Animal Science 2014; 27(1):140-146. 